\title{
Money's Unholy Trinity: devil, trickster, fool.
}

\author{
Angus Cameron
}

University of Leicester School of Management

Abstract

This paper argues that traditional associations between money and the devil remain with us - best seen in narratives about the (im)morality of money following the crisis of 2008. However such eruptions of moral concern about money and finance mask the more fundamental problems of a money economy that these associations sought to articulate in the first place. The fundamentally 'demonic' nature of money is not necessarily either about 'evil', but expresses the ontological insecurities both of money itself and of the social changes it brings about. The paper looks both at the long historical association between money and three overlapping 'psychologems' Trickster, Devil and Fool. It argues that these 'mythic' characters performed an important function in allowing the complexity of money to be articulated and embodied.

Keywords

Money, Devil, Trickster, Fool, Crisis, Mythology.

Introduction 
In September 2008, just after the collapse of Lehman Brothers, and as the full scale of the banking crisis was becoming apparent, a lone protestor appeared on Wall Street carrying a home-made cardboard placard. It expressed in rather abrupt terms what many people were feeling. Harking back to tales from an earlier crisis, in large black-painted letters it presented the banking community with an uncompromising invitation: 'Jump, you fuckers' (Hind 2009). As images of this placard spread widely on the internet, the main focus of attention, understandably, was on its blunt invitation to suicide. But what interests me here is its use of that particular ' $f$ ' word. While our protester was clearly at one level simply venting his spleen at the greed and stupidity of Wall Street, his choice of language was more subtle than it might first appear. It was, of course, intended to be offensive but the protester, knowingly or not, also invoked a much older history of money and banking. Specifically, the term used on his placard originated as a reference to the German banking family, Fugger (or Fokker, or, in Spanish, Fucare) (Ehrenberg 1929). The Fugger family rose to prominence during the 16th and 17th centuries and for a time completely dominated European finance. It was their notorious ruthlessness in getting to this position of power that caused their name to be linked to that older Anglo-Saxon word.

Even knowing this particular etymology, the term could still be taken as simply abusive - and for many using it over the centuries undoubtedly that was its primary function. But the word also carries a more sinister meaning, one emanating from the religious rather than the economic context in which the Fugger operated. Along with the abuse comes an allusion to aspects of money and banking that have been written out of modern economics. Now a by-word for dry technicality - all algorithms, graphs and mathematical derivatives - for much of its history finance was far more exciting; regarded as the stuff of the libidinous, tricksterish devil.

Although money has been regarded with considerable suspicion throughout its history (Kurke 1999, Davies 2002), its conjunction with the devil has a more recent and quite specific history. Much of this stemmed from the energetic reinvention of Satan by all sides during the religious wars of Reformation/Counter-reformation Europe (Burton Russell 1986). When Martin Luther nailed his '95 Theses' to the door of the Wittenburg Church in 1517, one of his main targets was the practice of selling 'indulgences' - absolution from worldly sin bought for money ${ }^{1}$. This meant that his energies were directed both against the Catholic Church for permitting such a corruption of faith, but more precisely against the Fugger. The Fugger bank, whose

\footnotetext{
${ }^{1}$ As a popular ditty of the time put it, 'As soon as the coin in the coffer rings, the soul from purgatory springs'. Attributed to the priest Johann Tetzel (1465-1519) this was specifically attacked in Luther's $27^{\text {th }}$ thesis.
} 
tentacles reached into all the commercial centres of Europe, had been granted the license to sell indulgences throughout the Holy Roman Empire and were thus regarded by Luther as the devil incarnate (Ehrenberg 1929). And if the Fugger were devils, the emergent system of finance capital over which they presided was ample evidence of evil abroad.

Between the 95 theses and our lone protestor, therefore, lies a 500 year history of connection between ancient modes of mythic personification and money. This is particularly true of the Devil, but I also want to include the closely related entities of Trickster and Fool. These three share important characteristics often perform very similar functions and have all at various times been associated with the material and moral ambiguities of money. These relationships have taken very different forms over the centuries and across the many places in which they have been articulated, but until comparatively recently have been consistently visible. They start to wane towards the middle of the $19^{\text {th }}$ century and, apart from sporadic reminders such as that on Wall Street in 2008, have by now largely vanished from popular consciousness ${ }^{2}$. What I want to explore here is what the mythic personification of money once achieved that might explain its longevity. I argue that it performed the important function - common to much that comes under the heading 'myth' - of representing (without resolving) tensions within and between social phenomena. If this was important to social understandings of money in past, what have been the consequences of losing this peculiar way of representing money more recently? I argue that modernist/rationalist models of money - money as economic fact - present us with a one-dimensional version of money that fails to encompass its profound and necessary complexity. The inability of bankers, politicians, economists and many other academics to adequately account for (let alone predict) the crises of 2008 and beyond are partly a consequence of the conceptual impoverishment of debates about money. Our protestor in 2008 , therefore, reminds us that there is much more to money than meets the (economistic) eye.

The paper first takes a necessarily brief look at the social function of myth. It then goes on to review the associations drawn between three inter-related entities - Devil, Trickster, Fool - and money. This will explore the origins of these associations in ancient mythology and religion, their recasting with the onset of the Reformation and Enlightenment (in Europe), their subsequent evolution and eventual (apparent) disappearance. The paper then returns to Wall Street in 2008 and beyond to argue that the 'libidinal

\footnotetext{
${ }^{2}$ The association between money and the devil endures long after the figure of Satan had started to dissipate from European Christian cultures and philosophy. Ernst Gellner (1958) attributes his demise to Descartes, though only to argue that this simply means that all philosophers believe in the 'devil' (as a core problem of explanation) from then on. This is, however, a metaphorical devil (cf, also, Lefebvre 1995)
} 
economy' represented by money's devils, tricksters and fools remains with us, but that we no longer have a language rich enough to adequately represent it.

The psycho-social function of myth.

Although there is a vast empirical, critical and theoretical literature on mythology, there is little agreement either over precisely what a myth is or, more importantly here, what its socio-cultural function might be. This is partly because analysis of myth tends to fall across disciplinary debates - theology, anthropology, literary criticism, classical studies, psychology - that do not always communicate very well with other, and which in any case often pursue different intellectual agendas. Indeed one of the few things that theorists of myth do seem to agree about is the impossibility of pinning down this diffuse and ubiquitous human social phenomenon to a single definition. Finnish folklorist Lauri Honko, for example, identifies seven ancient and twelve modern theories of myth and, although she offers her own working definition, necessarily ends up with a fudge allowing for context-dependent 'flexibility' (Honko 1984:51). In the same collection classicist GS Kirk concludes after his own overview of the main theories (1984:55):

Each of these universal theories [...] can be negated by citing many obvious instances of myth that do not accord with the assigned origin or function. Indeed the looseness of the term "myth" itself, and its wide range of applications in common usage [...], together with the failure of specialists to offer acceptable special definitions, suggest that it is a diverse phenomenon that is likely to have different motives and applications even within a single society - let alone in different cultures and at different periods.

This situation presents any analysis of 'myth' with both opportunity and problem. The opportunity arises from the interpretative freedom that such a varied and open field of study allows - not quite 'anything goes', but not far off it either. This then produces the problem that with no agreed definition any approach can fall into a teleological trap - any selection of that which is deemed to be mythic will inevitably be influenced by the argument one wants to advance. Partly to head off such problems I will make no attempt to define myth here, but rather suggest in a more open sense that the materials I wish to consider are related to, but not reducible to, the mythic. The various images and texts I shall allude to all draw on and re-present mythic characters, but are not themselves 'myths' in any conventional sense. Rather they pull in some of the functionality of myth - by appropriating mythic personifications often of great antiquity - but linked to the 
distinctly modern and, for want of a better word, 'real' issue of money. Modernity and reality are not necessarily inimical to myth, but neither do they meet such criteria commonly applied to myths such that they should be, for example, 'tales of the gods', 'traditional', 'sacred', 'ritualistic', etc. (cf. various essays in Olson 1980 and Dundes 1984).

What interests me here is not myth itself but the psycho-social function that myths and elements of the mythic perform. All human cultures produce them at some point, all still do, but the reasons why we do this are not always clear. Myth is somehow less than religion, but more than mere story. It is ancient and often considered sacred in some sense, but myth does not attract the reverence or respect accorded tot a Bible, Koran, Torah or other orthodox and/or institutionalised religious text. Indeed myths seem always to evolve and are reappropriated by other cultures and other times in ways that would be considered blasphemous or heretical had they the same status as 'scripture'. Myths deal with gods and monsters, but are widely accepted to be a popular or folk literature - stories about the gods by and for the people. This popular aspect of myth seems key to the ways in which they function in the social settings that produce them. Emerging from oral traditions, there may be all manner of rituals and traditions around their telling, but they are not 'owned' in quite the way that other texts are. Religion without a priesthood, perhaps?

So what are they for? Most, if not all of those narratives, written and oral, that come under the headings of myth, parable, fairy tale, story, saga, epic, etc. have in common an explication of aspects of social life that cannot be easily or logically resolved. This ranges from obvious common themes of good vs. evil, the vagaries of love, life and death, duty and rebellion and so on, but within them are woven many more mundane issues: family relationships, wealth, poverty, hunger, anger, revenge, social status, morality, etc. Myths weave these complex, intermingled and often paradoxical phenomena into coherent, embodied narratives. Coherent, though not necessarily resolved, real, or even credible, but presented in a narrative form that somehow 'makes sense'. It is very important, therefore, that myth-makers have access to a full panoply of magic, gods, monsters, heavens, hells and other useful stuff that can conveniently be used to demonstrate that the irreconcilable oddities of life have cause and meaning. The apparently random destruction of human life and livelihood thus becomes the work of an angry god or two. Crop failure or impotence are attributed to malevolent witchcraft (Rosen 1969). Unexpected (or undeserved) good fortune is a product of a capricious demon (Hyde 1998). The obvious fact that the world is bigger and more complex that we can ever rationally explain naturally suggests the existence of a supernatural domain to which all that otherness can be attributed. None of this stops the world as lived being a mess of contradiction, unfairness 
and paradoxy, but does at least provide a mode of explanation that, even if it cannot resolve our problems, at least makes them the stuff of a shared experience placed at a comforting narrative distance. In general, and over many centuries, all aspects of everyday life for most people were inflected to a greater or lesser extent by aspect of myth - all that we now readily dismiss as 'superstition', 'medieval' (in the sense of pre-modern) and, more explicitly, 'mere mythology' (as ignorant fantasy) (Olson 1980).

As such myths form a diffuse class of hermeneutic devices that in various ways give a dreamlike sense to the world around us (Jung 1956). Myths may be tales, this is to say, but they are also tools and they carry out some kind of work for us - conceptual, spiritual, social, aesthetic - that helps us to explain and/or live in the world. This means that myths - however defined - cannot be reduced to simple narrative stories that can be understood outside of the cultural context in which they are produced. Myths may travel between cultures and periods, but their meaning at any place or time depends on the reasons for their particular deployment and/or performance (Malinowski 1984) Partly because of this many theorists of myth emphasize its ontological role - one very different from the positivist and materialist ontologies characteristic of Enlightenment rationalism (Mason 1980, Oliver 1980, Dundes 1984). Indeed, much recent interest in mythology has been stimulated by a desire to push back against the process of 'demythologizing' the major religions in particular and society in general that accompanied the rise of rationalist and scientistic approaches to knowledge during the $19^{\text {th }}$ and $20^{\text {th }}$ centuries (Adorno \& Horkheimer 1944, Oliver 1980). Although led from critical hermeneutics traditions in the arts and humanities, this has also affected the natural sciences not least because of the 'relational ontologies' made necessary by quantum and relativity theory (Oliver 1980) and by the critical debunking of the absolutism of scientific method (Feyerabend 1975, 1987).

A key aspect of myth, and one that is crucial to its associations with money, is its capacity to capture duality the inherently ambiguous realm of the 'between'. Betweenness is a central aspect of mythology partly because in conjuring up the supernatural some way of communicating with and/or reaching it must be established. But the domain of the between is much more fundamental to mythology than simply facilitating the invocation of another place/space, because it is one of the main aspects of everyday life that it tries to make sense of. Whatever else they might be, myths are often concerned with relationships between people, communities and nature that seem ineffable. In this sense the 'sphere of the "between"', as philosopher and theologian Martin Buber described it, is a 'primal category of human reality' (Buber 2002: 241). He continues: 


\begin{abstract}
"Between" is not an auxiliary construction, but the real place and bearer of what happens between men; it had received no specific attention because, in distinction from the individual soul and its context, it does not exhibit a smooth continuity, but is ever and again reconstituted in accordance with men's meetings with one another; hence what is experience has been annexed naturally to the continuous elements, the soul and the world.
\end{abstract}

For Buber religion was the main means through which the 'sphere of the between' was to be represented, valorised and actuated. Long before he developed his particular mission - Buber was an influential promoter of Hasidic Judaism in the nascent Israel - myths of all kinds had played a crucial role in locating human relationships and foibles in a world in which the between was integral to reality (mythology's relational ontology (Oliver 1984)) and which had agency. Betweenness is not just another space like the physical world, but, as Buber suggests above is a 'bearer' of complex human interrelationships. In many instances the 'bearing' is carried out by a boundary-crossing embodiment of the between - something or someone uniquely able to move between states of being. There are many such entities, but those that interest us here - those mythic characters that come to embody money and markets - are primarily devil, trickster and fool.

The Power of Two: Devil, Trickster, Fool.

Although over their long histories our three characters overlap with one another ${ }^{3}$, there is only one place where they appear together. And when they do come together, it is to conjure up the demonic, ambiguous in-between power of money. In doing so they draw in a range of traditions associating the strange power of money to the 'sphere of the between' and that connect it to the mythic. This isolated moment of convergence takes place in Part 2, scene one of Goethe's Faust - the so-called 'paper money scene' (Goethe 2001, Shell 1980). The timing of their convergence is important here because it coincides with the beginning of the decline of an explicit association of money and myth that had circulated for many centuries. Although it had been in the making since the 1770s, the final version of Faust, including Part Two, was only completed in 1831. And whilst mythic embodiments of money had been commonplace throughout Europe until this point, Faust marks a conceptual watershed after which money increasingly takes its modern,

\footnotetext{
${ }^{3}$ They are often paired. Devil and fool, for example, were routinely conjoined in the figure of the 'vice' in medieval mystery plays. Often dressed as a fool but bearing a devilish name, the vice would act as an often scabrous intermediary between the 'serious' action on stage and the audience (cf. Cushman 1900).
} 
abstract form. Before it does so, however, Goethe treats us to a dramatic concatenation of money and the demonism of the between.

Part two of Faust opens with the German Emperor and his counselors agonising over how to deal with the finances of an Empire bankrupted by war and excess. The answer to this dilemma is provided by the demon Mephistopheles, who persuades the Emperor that he has no need of gold to manage his debts. Playing on the court's desperation, credulity and greed, Mephistopheles deploys a suitably convoluted argument, saturated with alchemical metaphors, to persuade even the most skeptical among them that the 'mining' of the power of the state and the gullibility of the public will produce paper money that will stand, 'für gutes Gold' (Goethe 2001). As Marc Shell (1980: 528) puts it in his much-cited essay on the depiction of money in Faust, 'If one could mine the minds of men for credit then one would not need to mine the earth for the thesaurical commodity gold'.

Shell and others argue that this scene extends the overarching themes of the play by echoing Faust's personal tragedy in Part 1. Just as Faust buys an illusion of worldly power by contracting his soul to the vampyric Mephistopheles - by signing it away in blood - so the Emperor signs away the moral and political power of the state for an illusion of wealth also represented as words on paper (Shell 1980). Faust contains many different strands, but the notion that a 'real', material, moral, spiritual past is being traded for a fraudulent, hollow, paper future runs throughout. The 'paper money scene' carries strong echoes of Martin Luther's battles with the Church, the Holy Roman Empire and the Fugger and his fears that the demon of money would undermine the moral fabric of church and state.

What has tended to go unremarked in the analysis of this extraordinary scene is the personal transformation that Mephistopheles undergoes in order to carry out his audacious scheme. One might have thought that wielding the power of the Devil would be enough, but Mephistopheles draws into himself the two other embodiments of the between to create an unholy trinity in pursuit of this ultimate monetary fraud. By the time the scene begins we already know that Mephistopheles is a demon - a manifestation of the Devil if not the Devil himself. This already complex character then redoubles himself both physically and rhetorically. The physical transformation comes in the form of Mephistopheles disguising himself as the Emperor's Fool. As the main protagonists enter the chamber, Mephistopheles mugs the Fool, steals his motley costume and takes his place at the Emperor's side. Now that we have Devil and Fool combined, Goethe adds a final archetype of dualism to the mix. The Emperor, bewildered that he signed up to such a demonic scheme, demands an explanation of his Schatzmeister (Treasurer). The Treasurer explains that it was the Emperor 
himself who ordered the adoption of the new money, but at the behest of a 'Tausendkünstler': trickster. This term does not translate directly into English, normally being transliterated as 'man of a thousand arts' which, although technically accurate, loses the meaning of the term. In fact Goethe is alluding to a line much used by Martin Luther which states that 'Der Teufel ist ein Tausendkünstler': the devil is a trickster (Luther 1529. cf, also Belhaj Kacem 2002).

In bringing these three together in one person, Goethe unites three inter-related figures which, for all their different histories, share the fundamental characteristics of duality and ambiguity. Goethe may be the first author to combine them in this way, but their interconnection was already well established. As Jung remarks in his analysis of the Trickster (1956:195):

...this contradictoriness [of the Feast of Fools] also inheres in the medieval description of the devil as 'simia dei' (the ape of God), and in his characterization in folklore as the 'simpleton' who is 'fooled' or 'cheated'. A curious combination of typical trickster motifs can be found in the alchemical figure of Mercurius; for instance, his fondness for sly jokes and malicious pranks, his powers as a shape-shifter, his dual nature, half animal, half divine, his exposure to all kinds of tortures, and - last but not least - his approximation to the figure of the saviour. These qualities make Mercurius seem like a daemonic being resurrected from primitive times, older even than the Greek Hermes.

For Jung, the Trickster is one of a series of 'psychologems' - foundational psychological figures shared by all human cultures and all individual humans - which underpin our individual psyches. Indeed Jung's belief in these primordial figures was decisive in his split from Freud who held that the individual psyche was a tabula rasa at birth, only subsequently shaped by education and experience (Papadopoulos 2006). We do not, however, have to revisit these early battles between psychoanalysts to accept the long-standing nature of the interrelationship between, and socio-cultural importance of, these three overlapping, mythic, characters.

Although they all appear in myths in the formal sense (notwithstanding the definitional caveats outlined above), none of the three has ever been wholly contained within a specific body of myth or, indeed, myth itself. Perhaps because of their inherently slippery characters, all three have over a very long time been periodically dragged from the domain of the myth and into the 'real' world. Their various embodiments, this is to say, are able to occupy both the mythic and the real without any apparent contradiction or loss of social meaning. So, for example, whilst the Fool is a common literary and mythic character, fools have also been 
very real. Jung above alludes to the European tradition of the 'Feast of Fools' in which social order was periodically inverted, but the fool also became a physical and powerful political figure in the form of the court jester (e.g. Henry VIII's Will Somers or James I's Archie Armstrong (Welsford 1935, Willeford 1969, Harris 2011)) and as part of the various 'fool societies' that flourished in many European cities through the $15^{\text {th }}, 16^{\text {th }}$ and $17^{\text {th }}$ centuries (Lenient 1883, Zemon-Davies 1975). The medieval fool was closely associated with theories and practices of sovereignty - capturing an embodiment of disorder at the very heart of order - and was therefore also linked to aspects of money (Willeford 1969). Indeed some of the bourgeois 'fool societies' in France, in addition to creating political hierarchies in pastiche of the 'proper' authorities, went so far as to issue their own coins during carnivals (Zemon-Davies 1975).

Despite the many different uses to which they are put and guises in which they appear, our three mythic figures perform whether in myth or 'reality' much the same function. Essentially this is their capacity to embody the 'between' - their fundamental duality. This dual nature is articulated both in the modes of their existence, but also in their physical appearance. The Devil has two horns and cloven hooves and exists as part of a supernatural twinning - what Jeffrey Burton Russell (1986) calls a 'doublet' - with God in the Judaeo-Christian tradition. Trickster is an ancient and ubiquitous character in folk tales from all human cultures and, whilst he or she can take many forms, almost always forms a character existing across or within boundaries (spatial, moral, gender, social, etc.) (Brown 1947, Jung 1956, Radin 1956, Hynes \& Doty 1993, Hyde 1998). As novelist Michael Chabon put it (2008:12), 'Trickster goes where the action is, and the action is in the border between things'. Trickster figures are routinely symbolised by their dual nature - most famously Hermaphrodite embodying both male and female characteristics in Greek mythology and his/her progenitor, the Trickster-in-chief Hermes, a mischievous god that represented boundaries, market places, money and theft and whose emblematic staff bore two intertwined serpents - like the Devil forming an abstracted, 'horned' figure (Brown 1947). The Devil, like Trickster, is also strongly associated with boundaries and other intermediary spaces - particularly crossroads. The Fool, linked to both trickster and Devil, likewise embodied duality: the servant that could mock the King, the idiot savant, the spirit of chaos at the heart of order (Lenient 1883, Welsford 1935, Williams 1979, Janick 1998). The Fool's costume - the motley - is either multi-coloured or bi-chromatic; striped fabric throughout the middle-ages being associated with the demonic - the 'devil's cloth' (Pastoureau 2001). In bringing these three together, therefore, Goethe is making a very strong statement about the nature of modern money: it is so false and duplicitous, it needs to force of all three to bring it into being. 
By the 1830s paper currency was still coming into wide circulation, but was regarded by many with considerable suspicion. This was partly because of earlier, failed experiments with paper currencies, particularly the infamous 'John Law scheme' which, a century earlier, had nearly destroyed the French economy and produced widespread misery (Murphy 1997, Bonney 2001). There is little doubt that in addition to invoking the Fugger Goethe, was referring directly to the Law scheme in Faust. Often painted as a rather Mephistophelean figure himself, Law had introduced a paper currency into a French economy suffering, like Faust's Empire, from a shortage of precious metal after years of war. Flaws in the design of the paper currency scheme, combined with governmental incompetence, fraud and the bursting of one of the first major speculative bubbles - the Mississippi Company, also a creation of John Law - produced a dramatic collapse of the French economy and massive price inflation, particularly for food, in the early 1720 s (Bonney 2001). Although by the time Faust was published paper currencies were rapidly becoming normalised, memories of such earlier disasters were still fresh which meant that the association between the 'new' monetary order and the demonic were powerful and resonant literary devices.

\section{The fall of the money devil}

Goethe's drama was, of course, extremely influential - rapidly becoming one of the great works of German literature and establishing the tale of the eponymous Faust (although it had been circulating long before Goethe adapted it) as a core morality tale: a modern myth. Despite this, the play is better known and more often analysed as one of personal tragedy - the delusional Faust wrestling his personal demons - than for its wider social, and particularly monetary, resonances. As suggested above, Faust arrives at a moment when the cultural economic life of Europe is changing very rapidly and demonic aspects of money are starting to recede. This can be seen in another play, this time French, which opened at the Théâtre des Variétés in Paris on December $5^{\text {th }} 1820$. Unlike Goethe's epic psychodrama, messrs. d'Artois and Rochefort's Le Diable d'Argent: Revue en une Acte et en Vaudevilles was a lightweight musical comedy aimed at the lowest common denominator of popular taste. As its tale unfolds - set to popular tunes of the day - various would-be merchants pitch their products to the eponymous Money Devil (essentially a suave venture capitalist in a natty gold suit) in the hope of winning his cash and the hand of his daughter, the lovely Recette. Not only are they thwarted by the Devil's cynical valet, Grossous (Fatpenny), but Recette, complete with gold hat and miniature cornucopia, is in any case only interested in her Italian opera buffa singer, the 
roguish Belami. Peppered with in-jokes and monetary puns, in the end the whole thing degenerates into a cheesy reflection on the state of comic opera.

Artois and Rochefort's dreadful play may not be a milestone in theatrical history, but it does tell us just how 'safe' the idea of the money devil had become by the 1820s. The 'Diable d'Argent' was the title of multiple series of popular prints that were produced in France and elsewhere in Europe from at least the early $17^{\text {th }}$ century onwards and were still circulating at the time the play opened. Unlike the benign silliness of the play, however, in the prints the Devil is far from human. The iconography of the prints evolves from their earliest known version which is rooted in Reformation ideology (de Meyer 1967). This early French print, dating from the second half of the $16^{\text {th }}$ century, shows a coin-covered demon rising from a treasure chest. On all sides, representatives of the great and the good - the Pope, bishops, princes, etc. - are trying to shoot the devil down with a vast arsenal of weapons ranging from cannons to bow and arrows. Entitled, 'Tous Estats Tirent à ce Diable d'Argent' (all estates shoot at the money devil) both the image and its accompanying poem depict the efforts of the powerful and supposedly respectable, all of whom 'want a piece of the money devil'

Later versions of the Diable d'Argent are less concerned with money's effects on the upper hierarchies of church and state, than on much more ordinary people ${ }^{5}$. In most, a hideous winged demon flies above a street-scene across which are arranged various 'typical' craftsmen. The Devil's body is made up entirely of coins. As he flies he empties money-bags onto of the mesmerised crowd below, pissing, farting and shitting coins into their outstretched hands. Some use the tools of their (abandoned) trades to try to catch the elusive coins. The precise cast of characters change, though there are common elements that always seem to appear: the artist, with a hat made from his palette, tries to shoot the devil down with a musket; the cordwainer tries to lasso him; the tailor (all puns intended) grabs his coin-clad tail only to find it broken off uselessly in his hands. In some versions, the Devil's coins find their way under the skirts of women in various states of moral decline, bakers abandon their loaves, judges and notaries scrabble for the cash. In one early version, the money devil has a secondary demon clinging to his leg, this one carrying the unmistakeable symbols of arch-Trickster Hermes/Mercury (the winged headdress and his staff - the caduceus) and who in turn carries 'le Greffier' (the clerk, symbolising bureaucracy) on his back. Produced in large numbers throughout Northern Europe, these images all tell the same story: money is a filthy and

4 A full transcript and translation of the poem, and the image itself, can be found here: http://xenotopia.wordpress.com/2012/01/24/the-first-money-devil/ (accessed 5-5-2014)

${ }^{5}$ A selection of these prints, all produced by the Épinal company in Paris from the early $18^{\text {th }}$ to late $19^{\text {th }}$ century can be found on the Baker Library website, here: http://www.library.hbs.edu/hc/cc/moneydevil.html (accessed 5-5-2014) 
satanic intervention in the proper ordering of society, distracting men and women from their proper trades and stations as they all vainly grub for cash. Interestingly, what is depicted in nearly all of them is a crosssection of petty bourgeois economic life, rather than society as a whole. Money, therefore, appears as a libidinal, demonic and tricksterish disruption of the 'normal' economic life of the town.

Although these images continue to be produced until at least the 1880 s, by then they seem to have lost their force as a commentary on the diabolical nature of the money economy. The devil remains a very common subject for both visual and literary arts, particularly in Paris, but less concerned with money and the market than as a symbol of the evils of modernity more generally. As David Pike (2007) has argued, the development of complex urban spaces, and especially the opening up of the underground of the cities, ushers in a very different function for the modern metropolitan devil who now finds himself occupying a new vertical spatial hierarchy. In France again, the Devil is also appropriated into new popular art forms that deploy him as a multi-faceted and satirical figure used to poke fun at a range of bourgeois social foibles. Several series of stereoscopic 'Diableries' for example, were produced in Paris from the 1860s to the end of the $19^{\text {th }}$ century, which create a parallel demonic Paris in which the habits of the real city are parodied by skeletons and devils (May, et al, 2013). Whilst these include a version of the Diable d'Argent (Series B, No3 in May et al 2013:194), it is much closer to the vaudeville version of d'Artois and Rochefort than to the prints.

\section{Beyond the mythic economy?}

Although it becomes little more than a source of entertaining imagery by the time the money devil finally vanishes from the popular media, the mythologies of devils, trickster and fools clearly carried an enduring resonance for several hundred years. They 'worked', in other words, for successive generations of European economic citizens as they sought to make sense of new, frightening and occasionally disastrous changes in social and economic life. It is no coincidence that ideas of money's demonic nature arise along with modern credit monies from the 1480s onwards. Innovations such as double-entry bookkeeping summoned into existence such phantasms as 'imaginary' and 'ghost' money, and set them loose in the ledgers of an emerging European merchant class (Einaudi 1953, Cipolla 1956). Devil, trickster and fool provided cogent images to variously describe, satirise and oppose these changes, because they embodied aspects of the troubling 'between' that had direct parallels with money. One of the key functions of money in all societies, after all, is to open up a transactional space between people. Money creates distance not just 
on the physical sense - though it's capacity to store and transmit value it certainly does that - but in many other ways too. As the 'universal equivalent' it transforms particular commodities into the general currency and, in doing so, flattens and neutralises their cultural and emotional content. Partly because of this transformative power, however, money itself stimulates powerful emotional responses. Although entirely anthropogenic - albeit that it's actual origins remain something of a mystery - money is a deeply mysterious substance (Einaudi 1953, Simmel 1991, Davies 2002). Indeed one line of argument maintains that money emerges from ritual, mythical practices (Desmonde 1967). Whilst we have become accustomed to ignoring this aspect of it, for thousands of years money's capacity to evade objective categorisation, to hover between material and abstract value (tale vs. weight), to be both nothing and everything at once (by having no intrinsic value, but being the metric for all other value) and, above all, to be self-procreating. This latter characteristic - money begetting money through interest charges, fractional reserve lending, etc. - has been the focus of much of the fear and loathing that money has attracted over the centuries; particularly from the major religions (Shell 1993, 1995). For both Christianity and Islam, a worldly object having the creative powers properly reserved for the deity is a sure sign of wickedness at large, hence both religions' longstanding prohibitions on usury.

Money, therefore, exhibited characteristics that lent itself naturally to an iconology derived more from the mythic than what we might now recognize (at least until recently) as a 'proper' economic discourse (Adorno \& Horkheimer). As hermeneutic devices, therefore, our unholy trinity in their very varied forms, represented the nature of money for audiences coming to grips with an evolving and often very alien phenomenon far more convincingly than would an economist's mathematized rationalist account later. Indeed, to return to one of the functions of the mythic outlined above, one of the key problems for those attempting to design and run modern monies was precisely its problematic ontology. The tense political struggle over the nature of what was to become the post-bellum US currency in the 1860s and 1870s, for example, revolved around arguments about what constituted the 'reality' of money - its ontological substance (Poovey 1993, Ingham 2004). In that instance 'ontology' referred chiefly to the nature of that which was to underpin the value of the currency - circulating credit in the form (chiefly) of agricultural mortgages (the 'greenbacks') versus the traditional \$US backed by gold reserves held by New York banks (the 'goldbugs') - but the problem of money's ontology goes far beyond that (Carruthers and Babb 1996, Ingham 2004). As Georg Simmel (1991) and many others since have noted, money, need have neither substance nor value to function - it only requires that we believe in it (Brown 1959, Goux 1990, Ingham 1994, Lyotard 2004). Just as traditional 
myths filled in the ontological gaps in complex social situations, so they provided mythic elements that could, for a time at least, do the same for money.

Whilst there is no doubt that Martin Luther and many of his $16^{\text {th }}$ century contemporaries genuinely believed in the existence of devils and the diabolical nature of money, by the 1880s the mysteries of money had largely been supplanted by its normalization, the curbing of its wilder fluctuations, its increasing connection to relatively stable fiscal states and all the other paraphernalia of the 'modern' economy (Poovey 1993, 1995). Money's 'betweenness' thus becomes an unthreatening, mundane fact rather than evidence of sinister supernaturalism.

Jean-Joseph Goux describes this process of the transformation of narratives of money as evidence of a profound change in the nature of the symbolic order of modern economies (1990: 120, emphasis original).

Now, not only has contemporary sociality, with its exchange and production processes, ceased to practice an emblematic mode of symbolization -- the one familiar to ancient societies (and in certain respects the one perpetuated in the language of dreams) -- but it tends to shatter the mirror of representation, opening on to a system of signifiers marked by the nonfigurative, the operational. This trend is not limited to a single agency, it can be read in many registers (aesthetic, economic, libidinal), gradually and unevenly affecting all social metabolisms and their signifying productions and leading toward the implantation of another sociosymbolic system.

Devils, trickster and fools belonged to that 'emblematic mode of symbolization' that, for Goux, has now been supplanted by the 'operational'. Because money now 'works' most of the time - which in practice means that the boundaries of its existence and function are only rarely challenged - it can operate without demanding the ancillary ontologies provided by the mythic. Fluctuating exchange or interest rates, which might impoverish me or enrich me, are articulated in terms of an internally coherent, systemic language that seems to be complete. I may no longer be able to afford my mortgage repayments, but this is the work of 'the market' rather than the intervention of a trickster god or the devil and his minions. My bad luck is my own fault - for not reading the market carefully, investing at the wrong time, for buying the wrong thing - and can thus no longer be located in a more complex supernatural, suprapersonal cosmos. The market and the money that circulates within it, therefore, seem to function as a system that it wholly coherent internally and thus has no need of mythic augmentation. Or, rather, it did until September 2008. 
The collapse of Lehmans, the exposure of insane risk-taking, the stratospheric salaries and bonuses, the graft and fraud at the heart of global finance reminded us all, if we chose to look, that the cool, rational neutral world of money remains firmly rooted in a libidinal economy (Lyotard 2004, Cameron et al 2011, Horvat 2014). Libidinal economy, although it tends to produce some very dense and complex theoretical arguments, at root describes a very simple aspect of all kinds of economies: they are systems for the distribution of things that people want and need. As such whilst it might comfort us to imagine that the monetary and trade systems are just big, self-regulating machines, in practice they are always, necessarily, run by and for people, and people are subject to all manner of desires, fears, prejudices and idiosyncrasies that no economic theory has ever been able to model - mathematically or otherwise. In other words, the events of 2008 and the many and varied explanations of them since have, if nothing else, revealed once again the inherent incompleteness of a rationalist ontology of money.

Whilst this was very clearly articulated by our lone protestor, his voice, whilst momentarily entertaining, was by no means the only one expressing doubts about the nature of money in the context of the crisis. Many commentators questioned the materiality of money by asking, once the scale of 'losses' were articulated by the banks, 'where all the money had gone' (Cameron 2014). When the answer to this was unsatisfactory usually that the money had never existed in the first place, but was a notional value of particular markets some went further, albeit only briefly, to ask, what is money anyway?

Such questions generally went unanswered and were, in any case soon swamped by governmental and regulatory attempts to explain and assuage the growing financial crisis gripping the global economy. Interestingly, however, those voices also, albeit usually unwittingly, echoed the libidinal fears of earlier narratives of the evils of money. This tended to take the form of blaming particular types of financial behavior - greed, risk-taking, ignorance, youthful exuberance, etc. - and particular classes of financier hedge fund managers, the young, the inexperienced - as all deviating from the 'proper' management of financial affairs. As argued elsewhere, the ways in which these narratives of deviant finance were articulated in the aftermath of 2008 , claim that libidinal behavior was a characteristic of a few aberrant people, and not of the market as a whole (Cameron et al 2011). 
Although the apportioning of blame during and since the events of 2008 has not resorted directly to the supernatural or the mythic, the sorts of language and imagery being used expresses similar sentiments. We may not blame devils, tricksters or fools by name, but we do attribute the same libidinal, capricious and/or foolish behaviours to those that brought us to the brink of catastrophe. The crisis was caused, according to subsequent accounts, by 'Gods that Failed' (Elliot \& Atkinson 2008), a 'Spectre at the Feast' (Gamble 2009), the pursuit of 'Fool's Gold' (Tett 2009), because of an 'Age of Greed' (Mason 2009) in which 'All the Devils are Here' (McLean \& Nocera, 2010) ${ }^{6}$. In other words, both participants in the troubled markets and their many critics, easily slip back into a language that alludes to the same mythic metaphors mobilized by Goethe and the various authors of Diable d'Argent. At one level, of course, these are simply phrases used to dramatise accounts of otherwise dull economics and sell books. But the antiquity of such imagery and associations suggests that they are being used because they seem to capture something more complete about the functioning of economies than standard, technical accounts can manage. Secularised accounts of money and markets, this is to say, are not as free from the mythic-inflected narratives of the past as they would like to believe. As Norman O Brown argued in his extraordinary essay 'Filthy Lucre' (Brown, 1959: 240):

Modern secularism and its companion Protestantism, do not usher in an era in which human consciousness is liberated from inhuman powers, or the natural world is liberated from supernatural manifestations; the essence of the Protestant (or capitalist) era is that the power over this world has passed from God to God's negation, God's ape, the Devil. And already Luther has seen in money the essence of the secular, and therefore the demonic. The money complex is the demonic, and the demonic is God's ape; the money complex is therefore heir to and substitute for the religious complex, an attempt to find God in things.

It is not just that modern money and economics have developed their own new 'mythologies' - though in the blind faith we are expected to have in the rational and impersonal power of markets, that is clearly also the case - but that we have developed an economic ontology that denies, but has been unable to transcend those aspects of economic behavior that myth once helped us to make sense of. As Brown suggests, money itself has assumed the role of embodying the 'between' once given form by devil, trickster and fool -

\footnotetext{
${ }^{6}$ Lehmans itself was very quickly recast as the 'Bank of Evil' in the animated film Despicable Me (Coffin \& Renaud 2010).
} 
homo economicus put forward as an abstracted and emasculated reduction of these older and more complex beings (Brown 1959: 238. Cf. also Adorno and Horkheimer 1944). This is not to suggest that we should therefore revive the mythic devil, trickster and fool, but that we never managed to get rid of them. The events of 2008, captured by the protestor on Wall Street, brought us up against the limits of the pseudosecular ontology of modern financial economics and forced us to confront again if only for a short moment the unstable, libidinal, in short, human aspects of money. To return to a phrase used by Goux in the quote above, mythology was part of a 'mirror of representation' (emphasis added) supposedly shattered by the secularization and normalization of money. Mythology, therefore, was a means by which we could see ourselves, warts and all. In other words, the symbolic system of the myth, which very specifically embodies ambiguous social relations and phenomena and, in doing so, represents them without resolution, has been partially supplanted by a new sociosymbolic system that eroticises the unitary and the rational, but retains an ineradicable connection back into that older, deeper symbology that has not been lost. This is not just because we retain it, as Goux suggests, in the language of dreams, but because we retain it in everyday speech acts that both describe and enact the libidinal economy of the mythic. As Adorno and Horkheimer argued in their Dialectic of Enlightenment the attempt to rid us of the mythic has if anything produced the opposite. In their words (1944: 11-12), 'Just as the myths already realize enlightenment, so enlightenment with every step becomes more deeply engulfed in mythology'.

What failed in 2008 (and since), therefore, was not just the technical operation of an otherwise functioning monetary machine, but an entire system of reductively representing the economy. The failure of economists and bankers either to predict or to explain the crisis is a product not just of their use of inadequate mathematical models, but the universal adoption of an impoverished language to describe economic 'facts' that could not capture their variety and complexity. The very rapid reappearance of libidinal language and metaphor steeped in the mythic, suggests that such 'primitive' elements in the explanation of economic behavior are more sophisticated than that with which we have replaced them. Whether we embody it in devils tricksters and fools or not, our failure to embrace the ambiguity of money as a fundamental aspect of its functioning means that our 'rational' explanations of it are anything but. How rational can it be to manage an economic system based on a systematic denial of its libidinal foundation? I say this not out of nostalgia for the mythic as such, but because it at the very least allowed us a means to debate, challenge and, albeit often uneasily, accommodate the inherent peculiarities of money. If, as many have called for, we need a 
different type of "post-crash economics', then we also need a different (older) type of economic language through which it can be articulated.

\section{Acknowledgements}

This paper was originally presented at the 'Myth and the Market' conference held in Carlingford in June 2014. I am extremely grateful to its organisers - Norah Campbell, Donncha Kavanagh, John Desmond, James Fitchett, Pierre McDonagh, Aidan O'Driscoll and Andy Prothero - for creating such a warm and productive event and for providing a unique venue for the first public airing of the above. I am also grateful to the two anonymous reviewers who provided enthusiastic and valuable comments on the first draft. My apologies to them both if I have not been able to incorporate all of their points here, and to one of them for appearing to side with that fucker Martin Luther. This was entirely inadvertent as I am very firmly on the side of the devil.

References

Belhaj-Kacem, M, 2002, Théorie du Trickster, Paris, Sens \& Tonka.

Bonney, R, 2001, France and the first European paper money experiment', French History, Vol. 15, No.3: 254-272.

Brown, N.O., 1947, Hermes the Thief: The evolution of a myth, Madison, University of Wisconsin Press.

Brown, N.O., 1959, Life Against Death: The psychoanalytic meaning of history, Middletown, Conn., Wesleyan University Press.

Buber, M, 2002 [1947], Between Man and Man, London, Routledge Classics.

Burton Russell, J, 1986, Mephistopheles: The Devil in the modern world, Ithaca, Cornell University Press.

\footnotetext{
${ }^{7}$ http://www.post-crasheconomics.com/ (accessed $25^{\text {th }}$ February 2015)
} 
Cameron, A, Nesvetailova, A \& Palan, R 2011: 'Wages of Sin? Crisis and the libidinal economy', Journal of Cultural Economy, 4:2, 117-135

Cameron, A, 2014, 'Where has all the money gone? Materiality, mobility and nothingness'. Finance and Society, Vol.1, No,1: in press.

Carruthers, BG \& Babb, S, 1996, 'The Color of Money and the Nature of Value: Greenbacks and Gold in Postbellum America', The American Journal of Sociology, Vol.101, No.6: 1556-1591.

Cipolla, CM, 1956, Money, prices, and civilization in the Mediterranean world, fifth to seventeenth century, Princeton, Princeton University Press.

Chabon, M 2008, 'Trickster in a Suit of Lights', Maps and Legends, New York, Harper Perennial.

Coffin, P \& Renaud, C, 2010, Despicable Me, Paramount Pictures.

Cushman, LW, 1900, The Devil and the Vice in English Dramatic Literature before Shakespeare, Halle, Max Niemeyer.

Davies, G, 2002, A History of Money from Ancient Times to the Present Day, Cardiff, University of Wales Press.

de Meyer, M, 1967, Le Diable d'Argent: Évolution du theme du XVI-ieme au XIX-ieme Siècle', Arts et Traditions Populaires, Vol. 15, No. 3/4: 283-290.

Desmonde, WH, 1962, Magic, Myth and Money: The Origin of Money in Religious Ritual, New York, The Free Press of Glencoe.

Dundes, A (ed) 1984, Sacred Narrative: Readings in the theory of myth, Berkeley, University of California Press.

Ehrenberg, R, 1928, Capital and Finance in the Age of the Renaissance: A study of the Fuggers and their connections, London, Jonathon Cape.

Einaudi, L, 1953, 'The Theory of Imaginary Money from Charlemagne to the French Revolution.', in Lane \& Riemersma, (eds.), Enterprise and Secular Change: Readings in Economic History, Homewood, III., Richard D Irwin Inc: $229-261$ 
Elliot, I. \& Atkinson, D. 2008 The Gods That Failed: How Blind Faith in Markets Has Cost Us Our Future, Bodley Head, London.

Feyerabend, P, 1975, Against Method, London, Verso.

Feyerabend, P, 1987, Farewell to Reason, London, Verso.

Furnham, A \& Argyle, M, 1998, The Psychology of Money, London, Routledge.

Gamble, A. (2009) The Spectre at the Feast: Capitalist Crisis and the Politics of Recession, Palgrave

Macmillan, Basingstoke.

Gellner, E, 1958, The Devil in Modern Philosophy', in The Devil in Modern Philosophy (Selected Philosophical Themes), London, Routledge: 3-7.

Goethe, JW, 2001, Faust: A Tragedy (trans. Walter Arndt), New York, Norton Critical Editions.

Goux, J-J, 1990, Symbolic Economies: After Marx and Freud, Ithaca, Cornell University Press.

Harris, M, 2011, Sacred Folly: A new history of the Feast of Fools, Ithaca, Cornell University Press.

Helleiner, E, 2003, The Making of National Money: Territorial Currencies in Historical Perspective, Ithaca, Cornell University Press.

Hind, D, 2009, ,Jump, You Fuckers!‘, mimeo, widely available online. Accessed 25th February 2015 from http://www3.nd.edu/ druccio/documents/JumpYouFuckers.pdf.

Honko, L, 1984, The Problem of Defining Myth, in Dundes, A (ed.), Sacred Narrative: Readings in the theory of myth, Berkeley, University of California Press:41-52

Horvat, S, 2014, 'It's the Libidinal Economy, Stupid!', Aljazeera Opinion, January $21^{\text {st }}$. Available from: http://www.aljazeera.com/indepth/opinion/2014/01/it-libidinal-economy-stupid-201411991730302886.html (accessed 5-5-2014)

Hyde, L, 1998, Trickster Makes This World: Mischief, Myth and Art, New York, North Point Press 
Hynes, WJ \& Doty, WG, 1993, Mythical Trickster Figures: Contours, contexts, and criticisms, Tuscaloosa, University of Alabama Press.

Ingham, G, 2004, The Nature of Money, Cambridge, Polity Press.

Janick, VK, ed., Fools and Jesters in Literature, Art and History: A Bibliographical Sourcebook, Westport, Conn., Greenwood Press

Jung, CG, 1956, 'On the psychology of the trickster figure', in Radin, P, The Trickster: A study in American Indian mythology, New York, Schocken Books: 195-211.

Jung, CG, 2001, Modern Man in Search of a Soul, London, Routledge Classics.

Kaiser, W, 1964, Praisers of Folly: Erasmus, Baudeliare, Shakespeare, London, Victor Gollancz.

Kirk, GS, 1984, On Defining Myths, in Dundes, A (ed.), Sacred Narrative: Readings in the theory of myth, Berkeley, University of California Press: 53-61.

Kurke, L, 1999, Coins, Bodies, Games, and Gold: The Politics of Meaning in Archaic Greece, Princeton, Princeton University Press.

Landreth, D, 2012, The Face of Mammon: The matter of money in English renaissance literature, Oxford, Oxford University Press.

Lenient, C, 1883, La Satire en France au Moyen Age, Paris, Librairie Hachette.

Lefebvre, H, 1995, 'Third Prelude: The Metamorphoses of the Devil', in Introduction to Modernity, London, Verso: 56-64.

Luther, M, 1580, Der große Katechismus various editions in German and English. Full version of the 1529 German text available from http:// www.theologische-links.de (accessed 5-5-2014).

Lyotard, J-F, 2004, Libidinal Economy, London, Bloomsbury.

Malinowski, B, 1986, 'The Role of Myth in life', in Dundes, A (ed), Sacred Narrative: Readings in the theory of myth, Berkeley, University of California Press: 193-206. 
Mason, H, 1980, Myth as an "Ambush of Reality", in Olson, A.M., (ed.), Myth, Symbol and Reality, Notre Dame, University of Notre Dame Press.

Mason, P., 2009, Meltdown: The End of the Age of Greed, Verso, London.

May, B, Pellerin, D \& Fleming, P, 2013, Diableries: Stereoscopic adventures in Hell, London, The London Stereoscopic Company.

McLean, B and Nocera, J, 2010, All the Devils are Here: The hidden history of the financial crisis, Harmondsworth, Penguin.

Murphy, AE, 1997, John Law: Economic Theorist and Policy-Maker, Oxford, Oxford University Press.

Olson, A.M., (ed.), 1980, Myth, Symbol and Reality, Notre Dame, University of Notre Dame Press.

Papodopoulos, RK (ed), The Handbook of Jungian Psychology: Theory, practice and applications, London, Routledge.

Pastoureau, M, 2001, The Devil's Cloth: A history of stripes, New York, Washington Square Press.

Pike, D, 2007, Metropolis on the Styx: The underworld of modern urban culture, 1800-2001, Ithaca, Cornell University Press.

Poovey, M, 2003, The Financial System in Nineteenth-Century Britain, Oxford, Oxford University Press.

Poovey, M, 1995, Making a Social Body: British Cultural Formation 1830-1864, Chicago, Chicago University Press.

Radin, P, 1956, The Trickster: A study in American Indian mythology, New York, Schocken Books.

Ritter, G, 1997, Goldbugs and Greenbacks : The Antimonopoly Tradition and the Politics of Finance in America, Cambridge, Cambridge University Press.

Rosen, B, (ed) 1969, Witchcraft in England, 1558-1618, Amherst, University of Massachusetts Press.

Shell, M, 1980, Money and the Mind: The Economics of Translation in Goethe's Faust, Modern Language Notes, Vol. 95, No. 3: 516-562 
Shell, M, 1993, Money, Language, and Thought: Literary and philosophic economies from the medieval to the modern era, Baltimore, Johns Hopkins University Press

Shell, M, 1995, Art and Money, Chicago, University of Chicago Press.

Simmel, G, 1991, The Philosophy of Money, London, Routledge

Tett, G., 2009, Fool's Gold, Free Press, New York.

Welsford, E, 1935, The Fool: His Social and Literary History, London, Faber and Faber.

Willeford, W, 1969, The Fool and his Sceptre: A study in clowns and jesters and their audience, London, Edward Arnold.

Williams, PA, ed., 1979, The Fool and the Trickster: Studies in Honour of Enid Welsford, Cambridge, DS Brewer.

Zemon Davis, N, 1975, Society and Culture in Early Modern France: Eight Essays by Natalie Zemon Davis, London, Duckworth. 